THURSDAY, NOVEMBER I4, I9r8.

\section{WAR AND PEACE.}

THE turmoil which has shaken the civilised world to its foundations since August,. I9r4, ceased with the signing of the armistice with Germany on Monday, November II. A war which was deliberately provoked by advocates of brute force as a quick means of profitable aggrandisement has ended in the triumph of free nations allied against them: Freed from the incubus of the sabre-rattling military aristocracy of Prussia, and from the arrogance of an Emperor obsessed with the lust of conquest, the peoples of the world can again devote themselves to peaceful pursuits. Let us hope that the immoral militarism which led to the war, and sacrificed all principles of faithkeeping, justice, and humanity to attain its purpose, has been vanquisined for ever, and that we have seen the last struggle of a system which has dominated a large part of mankind for centuries.

In the early days of the war the Germans attempted to justify their belief in the justice of might by an appeal to the principles of Darwinism. The doctrine of the struggle for existence and the survival of the fittest cannot, however, sanction the ruthless exertion of force and the use of knowledge in the service of egotism and German Kultur. What it should signify is a movement towards higher planes of civilisation and the progressive development of the ethical nature of the human race. Evolution embodies the idea of social ethics, and makes the welfare of the community the essential purpose of the life of the creature. The idea that Darwinism implies nothing more than personal or national mastery at all costs is a crude misconception of this great principle, contrary to the best ends of civilisation.

The execrable deeds of the German land, sea, and air forces cannot be excuscd by reference to any sound principle of human progress. The spirit represented by such acts as the murder of innocent and unoffending non-combatants, heartless cruelty to women and children, and destruction of priceless buildings, is unworthy of twentiethcentury civilisation, and if it had prevailed in the end the sun of righteousness would have set on the world for centuries. Science and scientific principles must not be held responsible for these outward and visible signs of moral degeneration. Chlorine was used as a bleaching-powder for a hundred years before the Germans adopted it as a poison gas. Thermit was employed in the arts before it was used in incendiary bombs. Nitre is a fertiliser as well as a constituent of gunpowder.
The search for truth, and the discovery of new substances and forces in Nature, must not be impeded because unworthy use may be made of the results. What has to be done is to advance moral and ethical ideas to higher levels, so that new knowledge shall benefit the human race instead of being used to destroy it. Unless this is accepted, there will be an end of civilisation, for it is possible to conceive of a time when the forces at man's disposal will be so strong that a hostile army or an enemy's city may be destroyed almost at the touch of a button.

The popular mind has associated science and specialised education with German truculence and perfidy, and has even supposed that these conditions are necessarily related to each other. The characters exhibited by Germany in the conduct of the war are not, however, the result of overcultivation of science, but of a disastrous deficiency in moral and ethical training. The moral sense of a nation requires educating as well as the intellect; and higher civilisation demands that regard for truth and for the sanctity of a promise should be inculcated as being even more important possessions than the knowledge and use of recent discoveries and inventions. The war has shown that spiritual qualities count for much more than mere numbers. Our system of education was inefficient, but it produced a nation of young heroes. As, however, modern war is an affair of applied science-military, engineering, chemical, physical, medical, and economic-it is essential that those who take part in it should be provided with efficient scientific weapons. We have nothing to fear from making science the main axle of the educational coach instead of a fifth wheel, provided only that the right position is given to character training as well.

Though war is not an exact science, and cannot be reduced to a series of mathematical formulæ, tactics are constantly affected by the progress of science, and disaster may ensue if its effect is not correctly appreciated. A nation which lags behind, thereforc, in scientific development does so at the cost of a possible loss of supremacy in times of war. Scientific discovery, mechanical invention, and a highly technical organisation, as employed by the Germans, could be beaten only by similar forces arrayed against them. The scientific resources of the British nation were not drawn upon until the formation of the Ministry of Munitions in $19{ }^{15}$; and it is these that have provided the country with the scientific material and machinery by which, with similar efforts by our Allies, success has been achieved. If we had not had the chemists to produce the high explosives required, the majority of which are derived from 
coal-tar products, the noblest spirit would not have saved us from destruction.

When the Germans introduced the use of poisonous gases into warfare, immediate steps were taken by our military authorities to provide the troops with means of protection from them, and action was taken later to organise offensive as well as defensive measures. The matter was put into the hands of men of science, with the result that our gas attacks became more effective than those of our enemies. Sir Douglas Haig said in his despatch at the end of 1916: "The Army owes its thanks to the chemists, physiologists, and physicists of the highest rank, who devoted their energies to enabling us to surpass the enemy in the use of a means of warfare which took the civilised world by surprise.'

Science has been successfully called into service in many other directions. The meteorological establishments of the various countries involved in the war have done their utmost to provide greatly increased knowledge of the physics of the atmosphere for the immediate benefit of the armies. Both for naval and military operations, accurate forecasts have been much enhanced in value, and it has been of the highest importance to know the behaviour of the upper atmosphere for the information of the air services, and the condition of the surface atmosphere in relation to gun-sighting and range-finding. The organisation of the medical services for the prevention of disease, as well as the treatment of wounds, has been a veritable triumph. In consequence, the health of the Army has been better in the field than in peace-time, thanks to preventive inoculation, suitable food, and careful sanitation. Typhoid and paratyphoid fevers have been almost unknown, and tetanus has been under complete control. The most gratifying aspect of the whole war is that of the efficiency of the medical services.

Now that the war is practically over, we must prepare to meet other problems. Peace brings with it difficulties to be overcome which rival in magnitude the task of completely vanquishing our enemies. Problems will arise in connection with the health and physique of the nation which will tax the resources of the country's medical services to their utmost limit. The clash of arms will be succeeded by an equally strenuous industrial competition, and the reconstruction of the appalling devastation will call for all the resources of men of science and qualified administrators. We are faced with the necessity for better organisation of science and industry, and more efficient methods of production, if we are to maintain not only our position in the markets of the world, but also our ability to meet the vast expenditure which the war

NO. 2559 , VOL. IO2 has entailed. It is the duty of men of science to exert themselves to the utmost to secure due recognition and participation of science in the gigantic problems of national and international readjustment with which we are now confronted. In the United States every natural resource, every industry, and every ounce of their great power in money and in men has been made available for the national service for the certain commercial needs of peace no less than for the purposes of war. It is essential for us to make like efforts if we are to secure improvements in the industrial and commercial methods of pre-war days.

Will our people be true to the responsibility placed upon it for the future? If so, it must look to knowledge for its support, and not let itself be cajoled by the platitudes and promises of party politicians. Democracy has hitherto permitted itself to be swayed by eloquence, and has elected to be governed by men of words rather than by men of knowledge and action. The consequence is that men are entrusted with power, not because of any fitness they have shown for the offices they occupy, but because of their political influence or friendships. Scientific and technical experts have been used, but only as hewers of wood and drawers of water, while the administrative control has usually been in the hands of officials with no special qualifications for their directorships.

Much remains to be done by the State and in the city before science and other knowledge are given their full opportunities for increase and service. In originality and capacity of adapting means to ends, the British people is equal to any other in the world, but its attitude towards science is mostly indifferent, and the progress made is nothing compared with what would have been achieved under more stimulating conditions. When a new spirit prevails there will be no end to the rich gifts which science will pour into the lap of the human race. Then, if men are worthy of the fruits showered upon them, there will be an end of the night of weeping, and the advent of the morn of song which is our highest heritage. Let us do what we can to hasten the coming of this time, when men shall stretch out their hands to one another and encircle the world.

SCIENTIFIC UTILISATION OF COAL. Coal and its Scientific Uses. By Prof. William A. Bone. Pp. $x v+49 r$. (London: Longmans, Green, and Co., 1918.) Price 2 Is. net.

THIS volume, the latest addition to the already vast literature on that protean subject, Coal, is one of particular interest, as it is written from a somewhat novel point of view, the significance of 